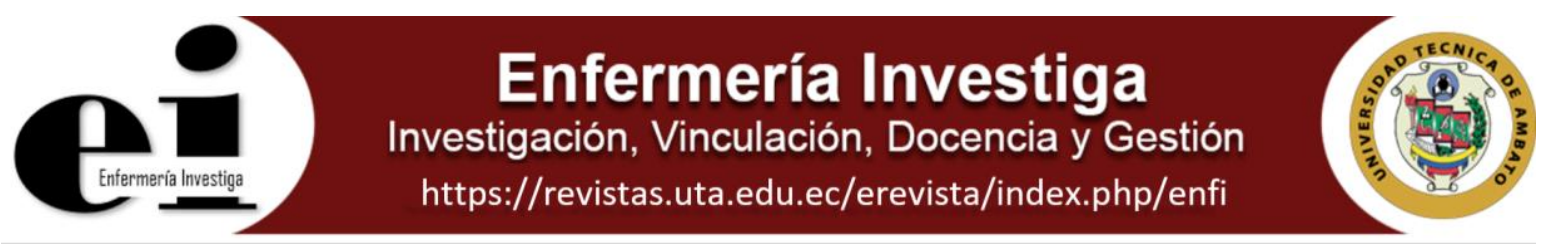

\title{
COGNITIVE INTERVENTION TO THE WOMEN WHO ATTEND THE "BREASTFEEDING SUPPORT GROUP"
}

\section{INTERVENCIÓN COGNITIVA A LAS MUJERES QUE ASISTEN AL GRUPO DE "APOYO DE LA LACTANCIA MATERNA"}

Gerardo Fernando Fernández Soto https://orcid.org/0000-0002-0246-03801,2, Paola Lisbeth Tamayo Martínez https://orcid.org/0000$0002-4252-9696^{3}$

${ }^{1}$ Career of Nursing. Research Nursery. Faculty of Health Sciences. Technical University of Ambato, Ecuador

${ }^{2}$ Researcher of the Project "Strategies for the prevention of childhood diseases: the success of modern pediatrics", Operational Research Unit of the Faculty of Health Sciences, Technical University of Ambato, Ecuador

${ }^{3}$ Student of the Nursing career. Faculty of Health Sciences. Technical University of Ambato, Ecuador

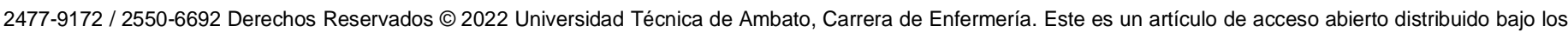

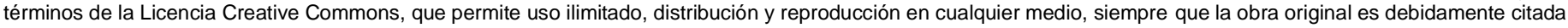

Received: March 1, 2021

Accepted: July 1, 2021

\begin{abstract}
Introduction: Breast milk is the best food to meet the nutritional needs of the child, exclusively for the first 6 months and up to two years of age, favoring the establishment of the mother-child bond. Objective: To carry out a cognitive intervention to the women who attend the "breastfeeding support group". Method: Quantitative research, with a quasi-experimental design, in a census sample made up of 11 pregnant women and 19 breastfeeding women. The lowa Infant Feeding Attitudes Scale (IIFAS) was used. Results: $33.30 \%$ (10) are between 33-35 years old, $63 \%$ (19) in the puerperium, $56 \%$ (17) with primary education, $60 \%$ (18) carry out agricultural / cattle raising activities, $53 \%(16)$ in free union. In the pre-intervention, the women had a positive attitude with a score of 17-48 towards artificial breastfeeding $83 \%(25)$, in the post-intervention the
\end{abstract}

positive attitude towards breastfeeding changed $87 \%$ (26), with a significant difference of $p<0.01$, in the items of the IIFAS instrument in the pre-intervention a mean and standard deviation of $2.07 \pm 1.16$, with an increase in the post-intervention of $4.48 \pm 0.65$, a significance difference $<0.05$ in the total of questions in the pre-intervention from 35.23 , increased after the intervention to 76.13 , their attitude changed to exclusive breastfeeding. Conclusions: the cognitive intervention increased the positive attitude towards exclusive breastfeeding, highlighting that a timely educational intervention of promotion, support and accompaniment during pregnancy and postpartum guarantees the duration and exclusivity of breastfeeding.

Keywords: breastfeeding, breastfeeding behavior, breastfeeding, knowledge, attitudes and health practice

Corresponding author: Gerardo Fernández Soto, MD, PhD. Email: gfernandez@uta.edu.ec.

\section{INTRODUCTION}

Breastfeeding in some countries has become a successful and responsible practice. However, worldwide, on-demand and exclusive breastfeeding becomes a public health problem $(1,2)$. In this sense, the World Health Organization (WHO) and the United Nations Children's Fund (UNICEF) implement actions and strategies to promote exclusive breastfeeding up to 6 months and then to start complementary feeding and maintain it for 2 years $(3,4)$. In addition, the United Nations General Assembly (UNGA) declared the ten support actions for breastfeeding. Its main objective is to promote child nutrition, food health and avoid globally 830,000 deaths of neonates and 20,000 deaths of women due to breast cancer $(2,4)$. If the practice of feeding with breast milk during the first hours of life of all human beings were successful, $86.5 \%$ of children would have a lower risk of mortality $(5,6)$.
In most countries, the rates of initiation of breastfeeding are higher than $90 \%$, but they decrease significantly after six months by $25 \%$. In the Americas region, $38 \%$ of children are breastfed exclusively up to six months and only $32 \%$ continue breastfeeding up to 24 months (5). The health and nutrition survey in Ecuador ESANUT registered an increase of $62 \%$ during the first six months and only $40 \%$ continue breastfeeding up to two years of age $(7,8)$. This is considered a serious problem that affects growth, psychomotor development and the immune system of infants. In Latin America, $18 \%$ of children keep this practice $(3,4,9)$.

The exclusivity and duration of breastfeeding is linked to modifiable factors such as low level of knowledge, negative attitudes and practices, myths and customs, sociodemographic factors such as low level of education, low income, occupation, maternal age, parity, lack of support and interventions by the health system $(10,11)$. Guaranteeing a successful practice not 
only requires the mother's desire, but also timely, efficient and effective educational interventions, support and follow-up by health personnel during the prenatal, delivery and postpartum period. In this sense, the nursing staff constitute a main and regulating axis for the successful practice of breastfeeding $(9,12)$.

The benefits of breastfeeding go beyond what is invaluable by the population. It favors the affective mother / child bond, it promotes optimal nutrition - healthy and free of diseases thanks to its immunological components. It prevents $64 \%$ of lower respiratory diseases such as Pneumonia, acute febrile episodes, stimulates psychomotor development and reduces the risk of ovarian and breast cancer $(5,8,15,13,14)$. For these reasons, the objective of the research work is to carry out a cognitive intervention to the women who attend the "breastfeeding support group".

\section{METHODS}

Quantitative research, quasi-experimental design (before and after) carried out in October 2020 - January 2021 (5). It's a census-type sample that included all the women who attend the "Breastfeeding Support Group", made up of 11 pregnant women and 19 breastfeeding women.

Intervention: a cognitive intervention was carried out. It aimed at women who attend the "breastfeeding support group" of Quero's Type C Health Center in prenatal and puerperium consultation who gathered in the meeting and breastfeeding rooms of Quero's Type C Health Center, Tungurahua Province, Ecuador. It included 45-minute health promotion, education and support meetings on breastfeeding. The educational intervention was adjusted to a technical guide for breastfeeding training validated by health regulations of the State of Mexico in 2016 (16), and the recommendations and norms established by the WHO and the United Nations Fund UNICEF (17). The following topics were considered: breast anatomy, types of nipples, stages of breast milk, benefits for the mother and her child, breastfeeding techniques and positions, signs of effective and ineffective sucking, mode of expression, preservation and storage of human milk, breastfeeding in times of COVID-19, and the Ten Steps to Full Breastfeeding.

Materials and equipment such as a computer with a projector were used for education, a chart with positive phrases regarding breastfeeding, an information booklet on the benefits of breastfeeding on demand, a breast model, and group discussions.

\section{Instruments:}

Sociodemographic data questionnaire: to collect information on: age, pregnancy period, childbirth, postpartum (puerperium), educational level, occupation, marital status, with closed and coded answers. It underwent content validity through an expert review consultation

The lowa Infant Feeding Attitudes Scale (IIFAS).

Questionnaire with a Cronbach's alpha of 0.72 , to evaluate attitudes towards different forms of infant feeding (positive attitude towards breastfeeding, positive attitude towards artificial feeding and neutral attitude) and to improve the intention of beginning and duration of breastfeeding in pregnant and postpartum mothers with an $82 \%$ intention to breastfeed for 24 months (3). As well as to identify the probability of breastfeeding in mothers and to assess the effectiveness of interventions in health programs. This instrument is made up of 17 items with five-point Likert-type responses, ranging from 1 (strongly disagree) to 5 (strongly agree). Eight questions in favor of breastfeeding $3,5,7,9,12,13,15,16$ while the remaining nine in favor of formula feeding with inverse assessment. The total score of the questionnaire fluctuates between 17-85. The highest score regards the positive attitude towards breastfeeding 70-85, 49-69 neutral attitude, $17-48$ positive attitude towards artificial feeding (18-20)

Before the cognitive intervention, the lowa Scale of Attitudes towards Infant Feeding (pre-test) was applied to the women in the breastfeeding support group. And a week later, at the end of the educational intervention, the post-test was performed.

\section{Ethical considerations:}

The development of the study was carried out taking into account the ethical principles for the Helsinki research. The confidentiality and anonymity of the surveyed participants was maintained and with prior authorization from the District 18D04 Ethics Committee and the Management Department of Quero's Type C Health Center (6).

The data obtained were processed through statistical software (SPSS Statistics 24.0 for windows), by calculating the numerical distribution, percentage, standard deviation, correlation coefficient and the Student's T-Test, Pearson's correlation linear regression coefficients, with statistical significance $(p<0.05)$. The results will be presented using tables

\section{RESULTS}

In the "breastfeeding support group" of Quero's Type C Health Center, $33.30 \%$ (10) are between $33-35$ years old, $26.70 \%$ (8) are between $20-22$ years old, $13.30 \%$ (4) ranges between $17-19$ years. Regarding the period, 19 women were interviewed who were in the puerperium with $63 \%$. Regarding the academic level, it was identified that $56 \%$ (17) have attended and completed primary school. The main economic activity $60 \%$ (18) is agriculture / cattle raising. As for the marital status 53\% (16) are in common law (table 1). 
TABLE 1

DISTRIBUTION ACCORDING TO SOCIODEMOGRAPHIC CHARACTERISTICS OF THE WOMEN IN THE BREASTFEEDING SUPPORT GROUP

\begin{tabular}{|c|c|c|c|}
\hline \multicolumn{2}{|c|}{$\begin{array}{c}\text { SOCIODEMOGRAPHIC } \\
\text { VARIABLES }\end{array}$} & \multirow{2}{*}{$\begin{array}{c}\text { FREQUENCY } \\
\text { No }^{0} \\
4 \\
4\end{array}$} & \multirow{2}{*}{ 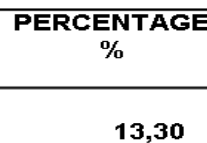 } \\
\hline Age (years) & $17-19$ & & \\
\hline & 20.22 & 8 & 26,70 \\
\hline & 23-25 & 2 & 6,70 \\
\hline & $27-29$ & 2 & 6,70 \\
\hline & 30-32 & 4 & 13,30 \\
\hline & 33-35 & 10 & $\mathbf{3 3 , 3 0}$ \\
\hline & TOTAL & 30 & 100,00 \\
\hline \multirow[t]{3}{*}{ Period } & Puerperium & 19 & 63,30 \\
\hline & Pregnancy & 11 & 36,70 \\
\hline & TOTAL & $\mathbf{3 0}$ & 100,00 \\
\hline \multirow[t]{4}{*}{ Academic level } & Primary & 17 & 56,70 \\
\hline & Studying Bachillerato & 11 & 36,70 \\
\hline & Finishing Bachillerato & 2 & 6,60 \\
\hline & TOTAL & 30 & 100,00 \\
\hline \multirow[t]{4}{*}{ Activity } & Student & 2 & 6,70 \\
\hline & Housewife & 10 & $\mathbf{3 3 , 3 0}$ \\
\hline & Farmer/Cattle raiser & 18 & 60,00 \\
\hline & TOTAL & 30 & 100,00 \\
\hline \multirow[t]{3}{*}{ Civil status } & Free Union & 16 & 53,30 \\
\hline & Married & 11 & 36,70 \\
\hline & $\begin{array}{l}\text { Divorced } \\
\text { TOTAL }\end{array}$ & $\frac{3}{30}$ & $\begin{array}{r}10,00 \\
100,00\end{array}$ \\
\hline
\end{tabular}

Source: Questionnaire applied to breastfeeding support group.

According to the attitude towards breastfeeding, it was evidenced in the pre-intervention that women had a positive attitude with a score of $17-48$ towards artificial breastfeeding $83 \%$ (25). Only one woman had a neutral attitude with a score of $49-69$ with $3 \%$ and $13 \%(4)$ of the mothers had a positive attitude towards breastfeeding with a score of 70-85 in the pre-intervention. In the post-intervention, the positive attitude towards breastfeeding changed $87 \%$ (26) with a significant difference of $p<0.01$ (Table 2).

TABLE 2

DISTRIBUTION ACCORDING TO THE TYPE OF ATTITUDE TOWARDS BREASTFEEDING OF THE WOMEN IN THE SUPPORT GROUP

TYPE OF ATTITUDE

TOWARDS

BREASTFEDING

Positive

attitude

towards

Breastfeeding

Neutral Attitude

Negative

attitude

towards

Breastfeeding

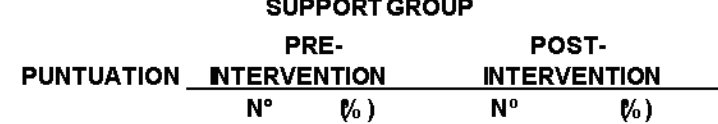

$N^{\circ}$

Vo)

$70-85$

49-69

$17-48$

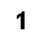

25
30

${ }^{*} \mathrm{p}<0,05$

Source: Iowa Infant Feeding Attitude Scale (IIFAS) applied to breastfeeding support group 
Regarding the items of the IIFAS instrument provided by the participants, a mean and standard deviation of $2.07 \pm 1.16$ was found in the pre-intervention. An increase in the post-intervention of $4.48 \pm 0.65$ with a significant difference $<0.05$ out of the total of the questions in the pre-intervention. It increased from 35.23 , after the intervention, to 76.13. Their attitude changed to exclusive breastfeeding (Table 3).

TABLE 3

DISTRIBUTION ACCORDING TOATTITUDES TOWARDS CHILD FEEDING BEFORE AND AFTER COGNITIVE INTERVENTION IN THE WOMEN OF THE BREASTFEEDING SUPPORT GROUP

\begin{tabular}{|c|c|c|c|c|c|}
\hline \multirow{2}{*}{$\mathrm{N}^{\circ}$} & \multirow{2}{*}{ Attitudes (options) } & \multicolumn{2}{|c|}{$\begin{array}{c}\text { Pre } \\
\text { intervention }\end{array}$} & \multicolumn{2}{|c|}{$\begin{array}{l}\text { Post } \\
\text { intervention }\end{array}$} \\
\hline & & M & DS & M & DS \\
\hline 1 & $\begin{array}{l}\text { The nutritional benefits of breast milk are only } \\
\text { maintained until the baby is weaned }{ }^{*}\end{array}$ & 2,47 & 1,2 & $4,73^{\star \star}$ & 0,45 \\
\hline 2 & $\begin{array}{l}\text { Artificial lactation is more convenient than } \\
\text { breastfeeding }\end{array}$ & 2,43 & 0,97 & $4,53^{* \star}$ & 0,51 \\
\hline 3 & $\begin{array}{l}\text { Breastfeeding increases the emotional bond between } \\
\text { mother and child }\end{array}$ & 1,67 & 1,42 & $4,53^{\star \star}$ & 0,51 \\
\hline 4 & Breastfeedinglacks iron* & 2,27 & 0,91 & $4,53^{* *}$ & 0,51 \\
\hline 5 & $\begin{array}{l}\text { Infants who are fed formula are more likely to be } \\
\text { overfed than those who are fed breast milk }\end{array}$ & 1,63 & 1,22 & $4,43^{* *}$ & 0,94 \\
\hline 6 & $\begin{array}{l}\text { Artificial feeding is the best choice if the mother plans } \\
\text { to work outside home* }\end{array}$ & 2,43 & 1,1 & $4,53^{* *}$ & 0,82 \\
\hline 7 & $\begin{array}{l}\text { Mothers who feed their babies with artificial milk miss } \\
\text { out some of the great joys of motherhood }\end{array}$ & 1,8 & 1,21 & $4,37^{* *}$ & 0,49 \\
\hline 8 & $\begin{array}{l}\text { Mothers should not breastfeed in public places like } \\
\text { restaurants* }\end{array}$ & 2,27 & 1,01 & $\mathbf{4 , \mathbf { 4 } ^ { \star * }}$ & 0,81 \\
\hline 9 & $\begin{array}{l}9 \text { Breast-fed babies are healthier than formula-fed } \\
\text { babies }\end{array}$ & 1,73 & 1,28 & $4,43^{\star *}$ & 0,5 \\
\hline 10 & $\begin{array}{l}\text { *Breastfed babies are more likely to be overfed than } \\
\text { formula-fed babies" }\end{array}$ & 2,7 & 1,15 & $4,4^{\text {** }}$ & 0,67 \\
\hline 11 & $\begin{array}{l}\text { Parents feel left out if the mother } \\
\text { breastfeeds* }\end{array}$ & 2,23 & 0,86 & $4,27^{\star *}$ & 0,91 \\
\hline 12 & Breast milk is the ideal food for babies & 1,53 & 1,14 & $4,53^{\star \star}$ & 0,68 \\
\hline 13 & $\begin{array}{l}\text { Breast milk is much easier to digest } \\
\text { than artificial milk }\end{array}$ & 1,9 & 1,49 & $4,57^{\star \star}$ & 0,5 \\
\hline 14 & $\begin{array}{l}\text { Artificial milk is as healthy for kids } \\
\text { as breast milk* }\end{array}$ & 2,33 & 0,99 & $4,57^{\star *}$ & 0,5 \\
\hline 15 & $\begin{array}{l}\text { Breast milk is more convenient than } \\
\text { artificial milk }\end{array}$ & 1,63 & 1,3 & $4,5^{* *}$ & 0,51 \\
\hline 16 & Breast milk is cheaperthan formula* & 2 & 1,7 & $4,63^{\text {** }}$ & 0,49 \\
\hline 17 & $\begin{array}{l}\text { Women who occasionally consume alcohol } \\
\text { should not breastfeed their baby* }\end{array}$ & 2,2 & 0,76 & $4,17^{\text {** }}$ & 1,18 \\
\hline TOTA & & 35,23 & 19,73 & $76,13^{\star *}$ & 10,98 \\
\hline GENE & ERAL AVERAGE & 2,07 & 1,16 & $4,48^{* *}$ & 0,65 \\
\hline
\end{tabular}

Item in favor of artificial lactation

** $p<0,05$

Source: lowa Infant Feeding Attitude Scale (IIFAS) applied to breastfeeding support group

\section{DISCUSSION}

Based on the results obtained from 30 mothers in pregnancy and puerperium period of the Quero Health Center, 33-35 year olds prevailed. However, there was also a group of adolescents, with a low educational level of primary studies, with work activity in agriculture and cattle raising; and in free union status. This was similar to the research of Ortega et al., where the average age 
was from 31-35 years, but they showed that they had university studies and work outside their homes (21). Unlike Niño et al., where the average age was between 20-24 years, secondary level studies and single marital status (22). In other research projects, a greater number of adolescents was established, as is the case carried out by Quezada et al., with ages between 13-17 years, occupations as housewives, with primary education and single marital status (23). Likewise Reyes et al., in their study, they ranged ages between 15 and 19 years, secondary level of education and marital status in common law union (24). In addition to the research work of Gómez, it was reported a predominance in age from 15 to 19 years, a higher educational level, economic activity as employees and single marital status (25). López et al, stated that among the sociodemographic characteristics, the average age of the mothers was 23 years old, $68 \%$ had a university level, $40 \%$ were housewives and $76 \%$ live in common law (26). And the study by Gil-Vargas et al, evidenced an average age between 19-30 years, high school level of education and free union as marital status (27).

In the current research project, a positive attitude towards breastfeeding was found with the post-intervention in $87 \%$ of the women, with a significant difference with the pre-intervention. In a similar way, Coronado and De la Cruz and Jácome et al. , in their research they determined the existence of a significant relationship between positive attitudes towards breastfeeding and the normal anthropometric assessment of children. Therefore, encouraging these positive attitudes in mothers will allow reducing children's nutritional problems and thus promote adequate growth and development $(28,29)$. On the other hand, Aguilar et al., showed a greater attitude towards artificial breastfeeding (30). For Hernández et al., a positive effect prevailed upon knowledge and attitudes towards breastfeedingIt is considered that breast milk, which must be given at any time, is enough to feed their children without the need for supplementation with formula milk. It is recommended up to two years of age and that all mothers have adequate milk production to feed their child. This decreased the percentage of mothers who did not breastfeed in public places and who believed that breastfeeding produced deformities in the mammary gland (31) Also López, et al., and Aguayo et al., established that the positive attitude towards breastfeeding favors exclusive breastfeeding up to six months of age of the child $(26,32)$. Similarly, Serrano et al, found a significant difference towards the positive action of breastfeeding after the educational intervention (33).

\section{CONCLUSIONS}

Early weaning is related to sociodemographic factors such as maternal age and low educational level. These determinants favor the abandonment of breastfeeding and child malnutrition. During attendance at the breastfeeding support group, it was observed that a large percentage of mothers got their questions answered and they modified negative attitudes towards breastfeeding. This determines a positive impact. In addition, it is confirmed that an educational intervention is effective and favorable when promotion through education, support and interaction of the nursing staff is appropriate from conception, pregnancy, delivery and postpartum stages.

\section{AKNOWLEDGEMENTS:}

Research Project "Strategies for the prevention of childhood diseases: the success of modern pediatrics", Operational Research Unit of the Faculty of Health Sciences, Technical of Ambato University, Ecuador.

CONFLICTS OF INTEREST The authors declare that they have no conflicts of interest.

\section{REFERENCES}

1. Da Graça L, Barbiéri M, Caetano M. Contribuciones de la intervención de enfermería de cuidados de salud primarios para la promoción del amamantamiento materno. Rev Latino-Am Enfer. 2011;19(2):2-9. Disponible en: https://www.scielo.br/pdf/rlae/v19n2/es_27.pdf

2. Tirano D, Pinzón O, González J. Factores de riesgo y barreras de implementación de la lactancia materna. Rev Esp Nutr Hum Diet. 2018;22(4):263-271 Disponible en: http://scielo.isciii.es/scielo.php?script=sci_arttext\&pid=S217451452018000400005\&lng=es. Epub 06-Abr-2020. https://dx.doi.org/10.14306/renhyd.22.4.442.

3. Quiñones V, Rodríguez P, Zango I. Exclusive breastfeeding and participation in daily life: an occupational perspective of motherhood. Cad BrasTer Ocup. 2020;28(1):86-110. Disponible en: https://www.scielo.br/scielo.php?script=sci_arttext\&pid=S252689102020000100086

4. Gómez J, Rojas M, Serrano K, Juárez M, Huerta A, Ramírez M. Intención de Lactar exclusivamente con Leche Materna: Un Estudio Basado en la Teoría de la Conducta Planeada. Clínica y Salud. 2020;31(1):13-20. Disponible en: http://scielo.isciii.es/scielo.php?script=sci_arttext\&pid=S1130-52742020000100002\&lng=es. 2020. https://dx.doi.org/10.5093/clysa2019a20

5. Dun-Dery EJ, Laar AK. Exclusive breastfeeding among city-dwelling professional working mothers in Ghana. Int Breastfeed J. 2016;11(1):23. doi: 10.1186/s13006-016-0083-8. PMID: 27602050; PMCID: PMC5012076.

6. Calvo C. Factores socioeconómicos, culturales y asociados al sistema de salud que influyen en el amamantamiento. REVENF. 2008;15:1-8. Disponible en:: file://C:/Users/HP2000/Downloads/Dialnet-FactoresSocioeconomicosCulturalesYAsociadosAISiste2745766.pdf

7. Remigio R, Terrazas A, Brito D, Ravelo Y. Some aspects related to exclusive breastfeeding in the first six months of life. Rev Cuba Pediatr. 2015;87(3):285-294.

Disponible en: http://scielo.sld.cu/scielo.php?script=sci_arttext\&pid=S0034-75312015000300004\&Ing=es.

8. Cevallos F, Vásquez G, Callay S, Falconí G. Lactancia materna Derecho que garantiza el crecimiento de la niña y el niño. CNII. 2020;1:2-28. Disponible en: file://C:/Users/HP2000/Desktop/DESARROLLO/LACTANCIA MATERNA Derecho que garantiza el cremimiento y desarrollo de la niña y el niño.pdf

9. Zhang K, Tang L, Wang H, Qiu L, Binns CW, Lee AH. Why do mothers of young infants choose to formula feed in China? Perceptions of mothers and hospital staff. Int J Environ Res Public Health. 2015;12(5):4520-32. doi: 10.3390/ijerph120504520. PMID: 25918908; PMCID: PMC4454923.

10. Giménez V, Jimeno B, Valles M, Sanz E. Prevalence of breastfeeding in a healthcare centre in Zaragoza (Spain). Social and health 
factors that influence it V. Rev Pediatr Aten Primaria. 2015;17(65):17-26. Disponible en:

76322015000100004\&lng=es. https://dx.doi.org/10.4321/S1139-76322015000100004.

11. Novillo N, Robles J, Calderón J. Beneficios de la lactancia materna y factores asociados a la interrupción de esta práctica. Enfermería Investig. 2019;4(5):29-35. Disponible en: https://revistas.uta.edu.ec/erevista/index.php/enfi/article/view/729

12. Souza EFC, Pina-Oliveira AA, Shimo AKK. Effect of a breastfeeding educational intervention: a randomized controlled trial. Rev. Latino-Am. Enfermagem. 2020;28:e3335. DOI: http://dx.doi.org/10.1590/1518-8345.3081.3335

13. Gancedo-García A, Fuente-González P, Chudáčik M, Fernández-Fernández A, Suárez-Gil P, Suárez Martínez V. Factores asociados al nivel de ansiedad y de conocimientos sobre puericultura y lactancia de embarazadas primerizas [Factors associated with the anxiety level and knowledge about childcare and lactation in first-time pregnant women]. Aten Primaria. 2019;51(5):285-293. Spanish. doi: 10.1016/j.aprim.2017.12.005. Epub 2018 May 24. PMID: 29803399; PMCID: PMC6839201.

14. Borre Ortiz Yeis Miguel, Cortina Navarro Carolina, González Ruíz Gisela. Lactancia materna exclusiva: ¿La conocen las madres realmente?. Rev Cuid. 2014; 5(2):723-730.: Disponible en: http://www.scielo.org.co/scielo.php?script=sci_arttext\&pid=S221609732014000200003\&lng=en. https://doi.org/10.15649/cuidarte.v5i2.84.

15. Matamoros N, Visentin S, Disalvo L, Varea A, Falivene M, Sala M, et al. Lactancia materna exclusiva y su relación con el estado nutricional de vitamina a del binomio madre-hijo. RevArgent Salud Publica. 2020;12:1-6. Disponible en: https://ojsrasp.msal.gov.ar/index.php/rasp/article/view/143

16. Gobierno del Estado de México, Secretaría de Salud, Instituto de Salud. Guía técnica para la capacitación de la lactancia materna. 2016;1: 47-192. Disponible en: https://www.ipomex.org.mx/recursos/ipo/files_ipo/2016/1/8/3cba2f3d0cf63020189411ee0a9d3e40.pdf

17. United Nations Children's Fund (UNICEF). Breastfeeding A Mother's Gift, for Every Child. unicef for every child. $2018 ; 5-20$. Disponible en: https://data.unicef.org/resources/breastfeeding-a-mothers-gift-for-every-child/

18. Abdulahi M, Fretheim A, Argaw A, H J. Adaptation and validation of the lowa infant feeding attitude scale and the breastfeeding knowledge questionnaire for use. Abdulahi al Int Breastfeed J. 2020;15 (24):1-11. Disponible en: https://internationalbreastfeedingjournal.biomedcentral.com/articles/10.1186/s13006-020-00269-w

19. Cotelo MDCS, Movilla-Fernández MJ, Pita-García P, Novío S. Infant Feeding Attitudes and Practices of Spanish Low-Risk Expectant Women Using the IIFAS (lowa Infant Feeding Attitude Scale). Nutrients. 2018;10(4):520. doi: 10.3390/nu10040520. PMID: 29690542; PMCID: PMC5946305.

20. Casal CS, Lei A, Young SL, Tuthill EL. A Critical Review of Instruments Measuring Breastfeeding Attitudes, Knowledge, and Social Support. J Hum Lact. 2017;33(1):21-47. doi: 10.1177/0890334416677029. Epub 2016 Dec 15. PMID: 28135474; PMCID: PMC6377936.

21. Ortega E, Piñero S, Alarcos G, Orta T, Jiménez V. Postnatal breastfeeding promote: support groups. nure Investig. 2010;49:1-13. Disponible en: file://C:/Users/HP2000/Downloads/511-Texto del artículo-2023-1-10-20150618.pdf

22. Niño Rosada Y, Delgado W, Meireles Y, Figueredo L, Barrios A. Risk factors that influence the abandonment of Breastfeeding . 2017-2018. Multimed. 2019;23(1028-4818 RPNS-1853):1278-1293. Disponible en: https://www.medigraphic.com/cgibin/new/resumen.cgi?IDARTICULO=96197\&id2=

23. Quezada C, Delgado A, Arroyo L, Dáz M. Breastfeeding prevalence and associated sociodemographic factors in teenagers Claudia. SCiELO México. 2008;65(1665-1146):19-25. Disponible en: http://www.scielo.org.mx/scielo.php?pid=S1665$11462008000100005 \&$ script=sci_arttext

24. Reyes Montero Yeidi, Alonso Uría Rosa María, Rodríguez Alonso Beatriz, Castillo Isaac Eugenio. Factores clínicos y sociodemográficos en lactantes con destete precoz. Rev Cubana Pediatr 2020; 92 (4): e671. Disponible en: http://scielo.sld.cu/scielo.php?script=sci_arttext\&pid=S0034-75312020000400003\&lng=es. Epub 20-Sep-2021.

25. Gómez L, Díaz C, Manrique R. Factores asociados con lactancia materna exclusiva hasta el sexto mes en madres adolescentes. Medellin, 2010. Re.salud pública. 2013;15(3):375-385. Disponible en: https://www.scielosp.org/pdf/rsap/2013.v15n3/374-385/es

26. López R, Covilla M, Morelo N. Cultural and social factors associated with exclusive breastfeeding in San Basilio de Palenque. Duazary. 2019;16(2):293-306. Disponible en: file://C:/Users/HP2000/Downloads/2961-Texto del artículo-9065-1-10-20190823.pdf

27. Gil-Vargas M, Dorantes-Vidal X, León-López M, Encuesta a mujeres puérperas de autoeficacia y actitud hacia la lactancia materna en un hospital de tercer nivel de atención. Rev Mex Pediatr. 2020;87(4):132-136. doi:10.35366/95822.

28. Coronado K, De la Cruz H. Maternal attitudes on infantile feeding and nutritional state of children from preschool institutions in Junín, Peru. Apunt Cienc Soc. 2016;06(01):70-73. Disponible en: http://journals.continental.edu.pe/index.php/apuntes/article/view/363

29. Jácome Á, Jiménez R. Validación de la lowa Infant Feeding Attitude Scale. Pediatria (Santiago) [Internet]. 2014;47(4):77-82. Disponible en: http://dx.doi.org/10.1016/S0120-4912(15)30143-9

30. Aguilar H, Coronado A, Gómez O, Cobos H. Adaptación de la lowa Infant Feeding Attitude Scale en población mexicana. INP-Acta Pedíatrica de México. 2016;37(3):149-158. Disponible en: http://www.scielo.org.mx/scielo.php?script=sci_arttext\&pid=S018623912016000300149

31. Pérez C, Díaz M, Romero A, Díaz J, Rodríguez V, Jiménez A. Eficacia de una intervención para mejorar conocimientos y actitudes sobre lactancia materna en adolescentes. RevEsp Salud Pública. 2018;92(18): e201806033.. Disponible en: http://scielo.isciii.es/scielo.php?script=sci_arttext\&pid=S1135-57272018000100411

32. Aguayo E, Hernández K, Puga K, Rodríguez M, Gómez J. Attitude towards breastfeeding related to primigravid women's age in two health centers. BIBLAT. 2018;3(5):14-18. Disponible en: https://biblat.unam.mx/hevila/Sanus/2018/no5/2.pdf

33. Serrano M, Lima J, Bueno Á. Diseño y validación de dos escalas para medir la actitud hacia la alimentación y la actividad física durante la adolescencia. RevEsp Salud Pública. 2012;86:253-268. Disponible en: http://scielo.isciii.es/scielo.php?script=sci_arttext\&pid=S1135-57272012000300005 